(c) Elsevier/INRA

Original article

\title{
Divergent selection for humoral immune responsiveness in chickens: distribution and effects of major histocompatibility complex types
}

\author{
M-H Pinard ${ }^{1, *, * *}$, JAM Van Arendonk ${ }^{2}$, \\ MGB Nieuwland ${ }^{1}$, AJ Van der Zijpp ${ }^{3}$ \\ 1 . Department of Animal Husbandry, Wageningen Agricultural University, Wageningen; \\ ${ }^{2}$ Department of Animal Breeding, Wageningen Agricultural University, Wageningen; \\ ${ }^{3}$ DLO-Research Institute for Animal Production Schoonoord, Zeist, The Netherlands
}

(Received 13 April 1992; accepted 20 November 1992)

\begin{abstract}
Summary - Chickens were selected for 10 generations for high and low antibody response to sheep red blood cells; in addition, a randombred control line was maintained. All birds ( $n=1602$ ) from the 9 th and 10th generations were typed for major histocompatibility complex B-types. All identified types were present in the control line but the selected lines showed divergent distributions. The $121 \mathrm{~B}$-haplotype was predominant in the high line in the form of 121-121 B-genotype, whereas the $114 \mathrm{~B}$-haplotype was most frequent in the form of 114-114 and 114-124 B-genotypes in the low line. To explain these frequency changes, effects of B-genotypes on the selected trait were estimated, using a mixed animal model. The B-genotypes were responsible for a significant part of variation of the trait within lines, but their effects differed between lines. These effects could be related partly to the changes in B-genotype distribution.

chicken / immune response / selection / animal model / major histocompatibility complex
\end{abstract}

Résumé - Sélection divergente sur la réponse immunitaire chez la poule: distribution et effets des types du complexe majeur d'histocompatibilité. Des poulets ont été sélectionnés pendant 10 générations sur la réponse immunitaire haute et basse à des globules rouges de mouton; une lignée témoin était également maintenue par accouplements

\footnotetext{
* Correspondence and reprints: MH Pinard, Laboratoire de Génétique Factorielle, INRA, 78352 Jouy-en-Josas Cedex, France

** On leave from the Laboratoire de Génétique Factorielle, Institut National de la Recherche Agronomique, Jouy-en-Josas, France
} 
au hasard. Tous les animaux $(n=1602)$ des générations 9 et 10 ont été analysés pour leurs types $B$ du complexe majeur d'histocompatibilité. Tous les types identifiés étaient présents dans la lignée témoin, alors que les lignées sélectionnées présentaient des distributions divergentes pour ces types $B$. L'haplotype $B 121$ était prédominant dans la lignée haute sous la forme du génotype B 121-121, alors que l'haplotype $B 114$ était le plus fréquent dans la lignée basse sous la forme des génotypes B 114-114 et 114-124. Afin d'expliquer ces changements de fréquence des types $B$, les effets des génotypes $B$ sur la réponse immunitaire aux globules rouges de mouton ont été estimés à l'aide d'un modèle animal mixte. Les génotypes $B$ étaient responsables d'une part significative de la variation du caractère intralignée, mais leurs effets étaient variables suivant la lignée. Ces effets pouvaient en partie expliquer les changements de fréquence des types $B$.

poule / réponse immunitaire / sélection / modèle animal / complexe majeur d'histocompatibilité

\section{INTRODUCTION}

In recent years, there has been a growing interest in improving the genetic resistance of domestic species to infectious diseases. This improvement may be accomplished indirectly by selective breeding for immune responsiveness and/or for genes or marker genes for immune responsiveness and disease resistance (Warner et al, 1987). Moreover, advances in molecular technique have opened promising ways for directly introducing advantageous genes into animals by genetic engineering (Lamont, 1989).

Successful selection experiments for high and low antibody response to sheep red blood cells (SRBC) have been reported in mice (Biozzi et al, 1979) and in chickens (eg Van der Zijpp et al, 1988; Martin et al, 1990). In the former experiment, Pinard et al (1992) have estimated heritability for the selected trait as 0.31 . However, even if the humoral response to $\mathrm{SRBC}$ is under polygenic control, some specific genes might play a major role, and the genes of the major histocompatibility complex (MHC) are prime candidates. The MHC genes encode highly polymorphic cell surface proteins that have been shown to play an important role in immune responsiveness and disease resistance in many species including chickens (Bacon, 1987; Gavora, 1990; Lamont and Dietert, 1990).

Estimation of MHC-type effects remains a delicate task, especially in the framework of selected outbred lines. Ignoring the relationships between individuals may, for example, often lead to overestimation of the MHC effect (Mallard et al, 1991). The choice of the method to estimate single gene effects separately from the background genes is therefore crucial (Kennedy et al, 1992).

The objectives of this study were to look for possible changes in MHC haplotype and genotype frequencies in lines of chickens divergently selected for 10 generations for antibody response to SRBC, and to estimate the MHC effects on the selected trait in order to understand the involvement of $\mathrm{MHC}$ in the regulation of the immune response. 


\section{MATERIALS AND METHODS}

\section{Selection lines}

The selection experiment has been described in detail elsewhere (Van der Zijpp et $a l, 1988$; Pinard et al, 1992). Briefly, chickens were bidirectionally selected from an ISA Warren cross base population for 10 generations. The selection criterion was the total antibody $(\mathrm{Ab})$ titer, $5 \mathrm{~d}$ postprimary immunization with $1 \mathrm{ml} 25 \%$ sheep red blood cells (SRBC) diluted in phosphate-buffered saline. Antibody titers measured against SRBC were expressed as the $\log _{2}$ of the reciprocal of the highest blood plasma giving complete agglutination. In addition to the high $(\mathrm{H})$ and low (L) lines, a random-bred control (C) line was maintained. Every generation, there were $\approx 300$ chicks each in the $\mathrm{H}$ and $\mathrm{L}$ lines and 250 chicks in the $\mathrm{Cline}$, from which $\approx 25$ males and 50 females in the $\mathrm{H}$ and $\mathrm{L}$ lines and $\approx 40$ males and 70 females in the $\mathrm{C}$ line were used to produce the next generation. In the 9th generation, the inbreeding level was $7.3,3.6$ and $9.4 \%$ in the $\mathrm{H}, \mathrm{C}$ and $\mathrm{L}$ lines, respectively. The numbers of birds in the $\mathrm{H}, \mathrm{C}$ and $\mathrm{L}$ lines of the ninth and tenth generations are given in table $\mathrm{I}$.

Table I. B-genotype frequencies (in \%) in the $\mathrm{H}, \mathrm{C}$ and $\mathrm{L}$ lines of the 9 th and 10th generations, ordered by decreasing number (No) of birds per genotype in the $\mathrm{L}$ line.

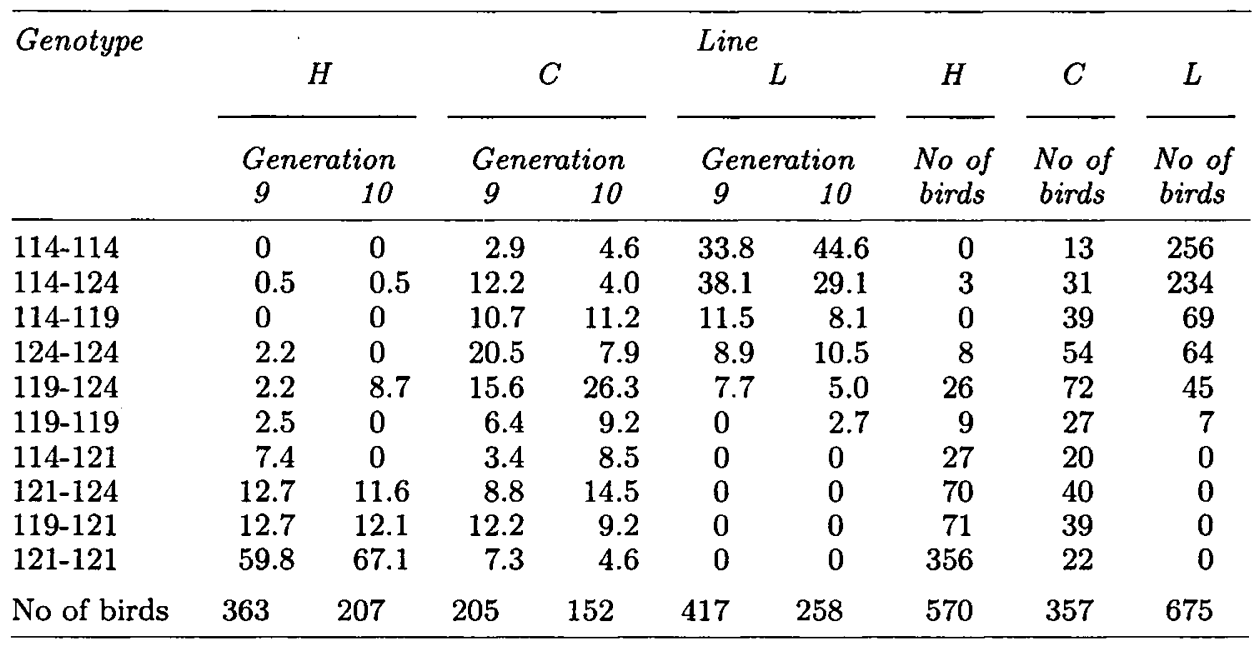

\section{Typing for MHC haplotype}

Major histocompatibility complex haplotypes were determined by direct haemagglutination, using alloantisera obtained from the lines. Four serotypes, provisionally called $\mathrm{B}^{114}, \mathrm{~B}^{119}, \mathrm{~B}^{121}$, and $\mathrm{B}^{124}$ were identified in the tested birds. As compared to known reference B-types, none of the serotypes identified in the lines was identical 
for both B-F and B-G. Only $\mathrm{B}^{114}$ and $\mathrm{B}^{119}$ showed similarities for B-G with $\mathrm{B}^{14}$ and $\mathrm{B}^{19}$, respectively, whereas $\mathrm{B}^{121}$ showed similarities for $\mathrm{B}-\mathrm{F}$ with $\mathrm{B}^{21}$ (Pinard et al, 1991 ; Pinard and Hepkema, 1992). A MHC genotype was defined as the combination of 2 haplotypes. Serological typing was performed on the parents of the 8th generation, on all the females and the selected males of the 8th generation, and on all the birds of the 9 th and 10th generations. Only the results of MHC typing in the 9 th and 10th generations were used in the analysis. Segregation of the haplotypes was checked for consistency within families over generations, and inconsistent data were removed from the analysis.

\section{Statistical analysis}

Comparison of MHC type frequencies between the lines was performed by $\chi^{2}$ tests.

Effects of $\mathrm{MHC}$ genotype on the $\mathrm{Ab}$ response were estimated within lines using the following mixed model:

$$
A b_{i j k l m}=\mu+\text { generation }_{i}+\text { sex }_{j}+\text { line }_{k}+M H C_{k l}+U_{i j k l m}+e_{i j k l m}
$$

Where:

$A b_{i j k l m}=$ the Ab titer of the $m$ th chick,

$$
\mu=\mathrm{a} \text { constant, }
$$

generation $_{i}=$ the fixed effect of the $i$ th generation $(9,10)$,

sex $x_{j}=$ the fixed effect of the $j$ th sex of the chick,

line $_{k}=$ the fixed effect of the $k$ th line $(\mathrm{H}, \mathrm{C}, \mathrm{L})$,

$M H C_{k l}=$ the fixed effect of the $l$ th $\mathrm{MHC}$ genotype within the $k$ th line,

$U_{i j k l m}=$ the random additive genetic effect on the $A b$ titer in the $m$ th chick and

$e_{i j k l m}=$ a random error.

The fixed effect of generation accounted for environmental differences between generations 9 and 10. The sex effect corrected for a higher Ab response to SRBC in females than in males. Relationships between individuals from the 10 generations and $\mathrm{Ab}$ data of the 9 th and 10th generations were used in this study. The mixed model was applied assuming a heritability of 0.31 , as estimated previously (Pinard et al, 1992). Solutions for the model were obtained using the PEST program (Groeneveld, 1990; Groeneveld and Kovak, 1990), which is a generalized procedure to set up and solve systems of mixed model equations containing genetic covariances between observations.

Differences between genotypes within lines were tested as orthogonal contrasts using the $F$ test values as estimated by PEST. The overall effect of genotypes in a line was estimated by testing, jointly against the error variance term $\sigma_{e}^{2}, n-1$ independent differences between genotypes, with $n$ being the number of genotypes in the line. 
Heterozygote superiority was estimated within-line for each available combination of haplotypes by testing the difference between the heterozygote genotypes and the average of their homozygous counterparts. The overall heterozygote superiority in a line was estimated by testing the difference between these heterozygote genotypes and the average of their homozygous counterparts.

The effect of haplotype $i$ was estimated within-line by testing the difference between genotype combinations comprised of the haplotype $i$ and their counterparts comprised of a reference haplotype $r$, as following: $\frac{\Sigma_{j}\left(\mathrm{Geno}_{i j}-\mathrm{Geno}_{r j}\right)}{p}$, with Geno $_{i j}$, and $\mathrm{Geno}_{r j}$ being the estimated effects of MHC genotypes comprised of haplotypes $i$ and $j$, and $r$ and $j$, respectively, and $p$ being the number of pairwise combinations.

\section{RESULTS}

\section{MHC distribution in the different lines}

Frequencies of MHC genotypes and haplotypes in the 9th and 10th generations for the $\mathrm{H}, \mathrm{C}$ and L lines are given in tables I and II, respectively. Frequencies of genotypes and haplotypes were significantly $(P<0.01)$ different between lines in the 9 th and in the 10th generation. In the $C$ line, all 10 possible genotypes were present, with a predominance of the 119-124 B-genotype, and the 119 and 124 B-haplotypes were prevalent. The distribution of MHC genotype and of MHC haplotype in the $\mathrm{H}$ line was opposite to those in the $\mathrm{L}$ line. The 121-121 B-genotype predominated in the $\mathrm{H}$ line, whereas the 114-114 and 114-124 B-genotypes were most frequent in the $\mathrm{L}$ line. In the $\mathrm{H}$ line, the $121 \mathrm{~B}$-haplotype frequency reached $79 \%$ at the expense of the 114 B-haplotype, which tended to disappear. On the contrary, the $121 \mathrm{~B}$-haplotype disappeared between the 8th and the 9th generation in the $\mathrm{L}$ line (data not shown). In the $\mathrm{L}$ line, the $114 \mathrm{~B}$-haplotype was found most compared to the 124 , and especially the 119 B-haplotypes.

Heterozygous birds were in the majority in the $\mathrm{C}$ line, whereas homozygous birds were most frequent in the $\mathrm{H}$ line and to a lesser extent in the $\mathrm{L}$ line. This tendency was more pronounced in the 10th generation.

\section{Estimation of $M H C$ genotype effects on the $A b$ response}

Estimates of MHC genotype effects on the $\mathrm{Ab}$ response to $\mathrm{SRBC}$ are given in table III. The overall effect of MHC genotypes was greater in the selected lines than in the $\mathrm{C}$ line, and the total genetic variance explained by MHC genotypes was greater in the $\mathrm{H}$ and $\mathrm{C}$ lines than in the $\mathrm{L}$ line. This high genetic variance in the $\mathrm{H}$ line arose from extreme estimate values of the 114-124, 119-119 and 124-124 B-genotypes despite their low frequency value. The ranking of genotypes according to their estimates of effects on the Ab titer differed between lines, especially between the $\mathrm{C}$ line and the $\mathrm{H}$ line. No significant changes in the estimates were observed when taking other input values for heritability between 0.2 and 0.4 (data not shown). 
Table II. Frequencies (in \%) of B-haplotype and of heterozygote birds in the H, C and L lines of the 9 th and 10th generations, ordered by decreasing haplotype frequency in the $\mathrm{L}$ line.

\begin{tabular}{|c|c|c|c|c|c|c|}
\hline \multirow[t]{3}{*}{ Haplotype } & \multicolumn{6}{|c|}{ Line } \\
\hline & \multicolumn{2}{|c|}{ Generation } & \multicolumn{2}{|c|}{ Generation } & \multicolumn{2}{|c|}{ Generation } \\
\hline & 9 & 10 & $g$ & 10 & 9 & 10 \\
\hline 114 & 4.0 & 0.2 & 16.1 & 16.4 & 58.6 & 63.2 \\
\hline 124 & 9.9 & 10.4 & 38.8 & 30.3 & 31.8 & 27.85 \\
\hline 119 & 9.9 & 10.4 & 25.6 & 32.6 & 9.6 & 9.3 \\
\hline 121 & 76.2 & 79.0 & 19.5 & 20.7 & 0 & 0 \\
\hline Hetero $^{1}$ & 35.5 & 32.9 & 62.9 & 73.7 & 57.3 & 42.3 \\
\hline
\end{tabular}

${ }^{1}$ Hetero: \% of heterozygote birds within lines.

Table III. Estimates of B-genotype effect on the $A b$ response to $\mathrm{SRBC}$ in the $\mathrm{H}, \mathrm{C}$ and $\mathrm{L}$ lines of the 9 th and 10 th generations.

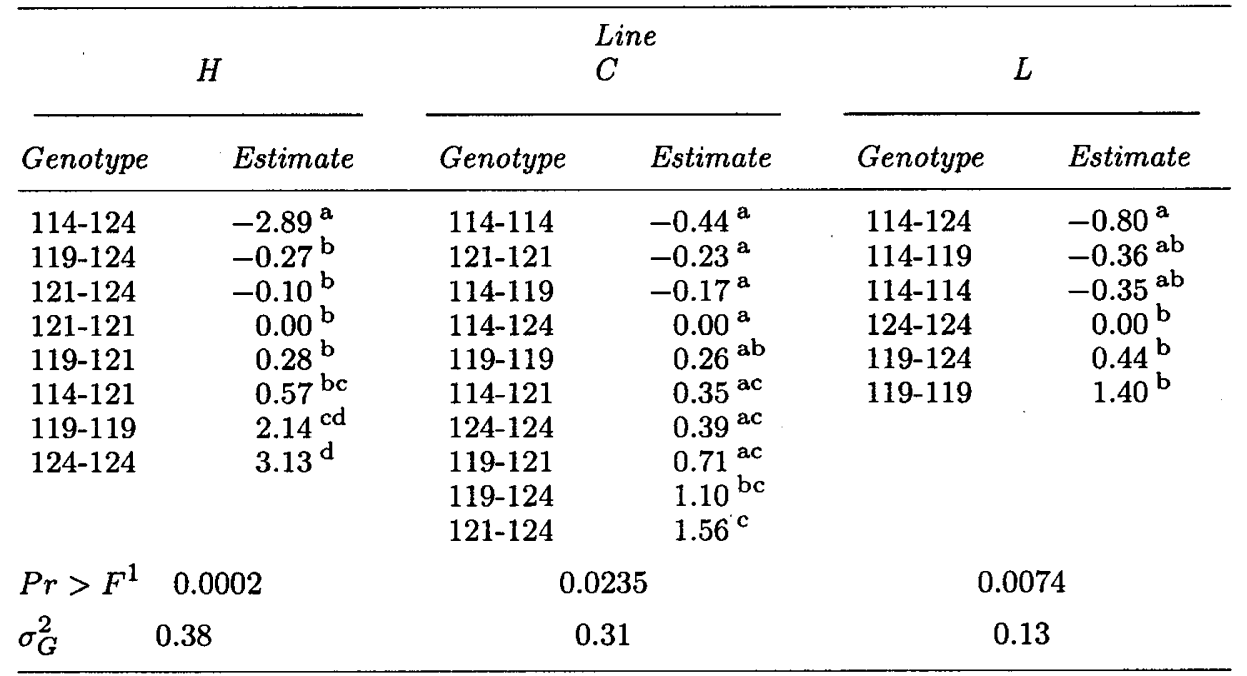

a,b,c,d Estimates with different superscripts indicate differences $(P<0.05)$ between genotypes within lines. ${ }^{1} \mathrm{Pr}>F$ indicates the overall effect of B-genotypes within lines. $\sigma_{G}^{2}=\Sigma_{i} p_{i}\left(e s t_{i}-\overline{e s t}\right)^{2}$ : total genetic variance arising from the MHC loci in generation $9 ; p_{i}$ and $e s t_{i}$ are, respectively, the frequency in the 9 th generation and the estimate of the $i$ th genotype, and $\overline{e s t}$ is the average genotype estimate $\left(\Sigma_{i} p_{i} e s t_{i}\right)$. 


\section{Estimation of heterozygote superiority}

Estimates of heterozygote superiority for each available combination and overall lines are given in table IV. In the C line, a moderately positive general effect of heterozygous genotypes was demonstrated. This positive effect appeared in the 119124 B-genotype, and was marked in the 121-124 B-genotype. In the $\mathrm{L}$ line, a general heterozygous disadvantage was non-significant. This negative effect, however, was significant only for the 114-124 B-genotype. In the $\mathrm{H}$ line, not all the heterozygous combinations could be evaluated because of missing genotypes. In the $\mathrm{H}$ line, there was a significant negative effect of heterozygous genotypes overall, and of the 121124 and the 119-124 B-genotypes.

Table IV. Heterozygote versus homozygote superiority ( $\pm \mathrm{SE}$ ) in the $\mathrm{H}, \mathrm{C}$ and $\mathrm{L}$ lines of the 9th and 10th generations.

\begin{tabular}{lccc}
\hline Genotype & \multicolumn{3}{c}{ Line } \\
\cline { 2 - 4 } & $H$ & $C$ & $L$ \\
\hline $114-119$ & & $-0.79 \pm 0.58$ & $-0.89 \pm 0.50^{\circ}$ \\
$114-121$ & & $0.68 \pm 0.70$ & $-0.63 \pm 0.24^{* *}$ \\
$114-124$ & & $0.03 \pm 0.57$ & \\
$119-121$ & $-0.79 \pm 0.47$ & $0.70 \pm 0.52$ & $-0.26 \pm 0.65$ \\
$119-124$ & $-2.91 \pm 0.72^{* *}$ & $0.78 \pm 0.40^{* *}$ & \\
$121-124$ & $-1.66 \pm 0.50^{* *}$ & $1.48 \pm 0.48^{* *}$ & \\
ALL $^{1}$ & $-1.79 \pm 0.42^{* *}$ & $0.60 \pm 0.31^{*}$ & $-0.59 \pm 0.38$ \\
\hline
\end{tabular}

${ }^{*, * *}$ : Significant superiority at the 0.05 and 0.01 levels, respectively; ${ }^{1}$ ALL indicates the overall superiority within lines.

\section{Estimation of MHC haplotype effects on the Ab response}

In the $\mathrm{C}$ and $\mathrm{L}$ lines, all possible combinations of haplotypes were present. Therefore, in these lines, the choice of a reference haplotype did not affect either the ranking, or the value of the differences between haplotype estimates. Results are presented in table $\mathrm{V}$ taking the $119 \mathrm{~B}$-haplotype as the reference. In the $\mathrm{H}$ line, haplotype effects were not estimated because it was not possible to write a linear combination of genotypes, which would estimate the difference between 2 haplotypes. The estimated $\mathrm{Ab}$ titer of the $114 \mathrm{~B}$-haplotype was significantly lower than the estimate of the $119 \mathrm{~B}$-haplotype in the L line (table V). In the C line, the estimated $\mathrm{Ab}$ titer of the $114 \mathrm{~B}$-haplotype was significantly lower than the estimates of the 121 and $124 \mathrm{~B}$-haplotypes in the $\mathrm{C}$ line.

\section{Relationship between the effects of $M H C$ types on antibody response and their frequency}

To determine whether the differences in MHC genotype and haplotype distribution between the lines could be explained by differences in genotype or haplotype effect 
Table V. Estimates of B-haplotype effect on the antibody response to SRBC in the C and $\mathrm{L}$ lines of the 9 th and 10 th generations.

\begin{tabular}{lcccc}
\hline \multicolumn{2}{c}{$C$} & \multicolumn{2}{c}{ Line } \\
\cline { 1 - 1 } Haplotype & Estimate & & Haplotype & Estimate \\
\hline 114 & $-0.54^{\mathrm{a}}$ & & 114 & $-1.00^{\mathrm{a}}$ \\
119 & $0.00^{\mathrm{ab}}$ & & 124 & $-0.61^{\mathrm{ab}}$ \\
121 & $0.12^{\mathrm{b}}$ & & 119 & $-0.00^{\mathrm{b}}$ \\
124 & $0.28^{\mathrm{b}}$ & & \\
\hline
\end{tabular}

The 119 B-haplotype was taken as a reference; ${ }^{a, b}$ : estimates with different superscripts indicate differences $(P<0.05)$ between haplotypes within lines.

on the selected trait, frequencies of MHC types and their estimated effects on the $\mathrm{Ab}$ titer were compared. When not considering the extreme values of rare genotypes in the $\mathrm{H}$ line, remaining genotype estimated effects were not significantly different from each other; therefore, results from the estimation of MHC genotype effect on the $\mathrm{Ab}$ response from the $\mathrm{H}$ line will not be considered.

The ranking of estimates of haplotype effects on the $\mathrm{Ab}$ response in the $\mathrm{L}$ line (table V), was in total agreement with the distribution of these haplotypes in the selected lines (table II). Likewise, the ranking of the 114, 119 and 121 B-haplotype effects estimated in the $\mathrm{C}$ line could explain the haplotype distribution in the selected lines.

Genotypes which were most frequent in the $L$ line had also, on the whole, lower effects on the $\mathrm{Ab}$ response than genotypes which were rare in the $\mathrm{L}$ line, as estimated in the $\mathrm{L}$ line (fig 1 ) and in the $\mathrm{C}$ line (fig 2). Genotypes which were most frequent in the $\mathrm{L}$ line had globally lower effects on the $\mathrm{Ab}$ response in the $\mathrm{C}$ line than genotypes which were most common in the $\mathrm{H}$ line (fig 2). The major exception was the 121-121 $\mathrm{B}$-genotype which was most frequent in the $\mathrm{H}$ line, but had a low effect on the $\mathrm{Ab}$ response in the $\mathrm{C}$ line (fig 2 ).

In conclusion, estimation on MHC genotype and haplotype effects on the $\mathrm{Ab}$ response in the $\mathrm{C}$ and $\mathrm{L}$ line could explain the observed distribution of $\mathrm{MHC}$ types in the $\mathrm{L}$ line and only partly those observed in the $\mathrm{H}$ line.

\section{DISCUSSION}

Changes of gene frequency may be due to genetic drift, difference in fitness of certain genotypes, or, in case of selection, to direct effect or linkage with genes affecting the selected trait (Falconer, 1989). Even after 10 generations, genetic drift is not likely to explain such dramatic changes of MHC type frequency in opposite directions. Moreover, previous genetic analysis of 9 generations did not show any apparent genetic drift, and inbreeding, which affects genetic drift, was low (Pinard et al, 1992). Associations between MHC types and fitness traits have been demonstrated in avian (Gavora et al, 1986; Nordskog et al, 1987) and mammalian 


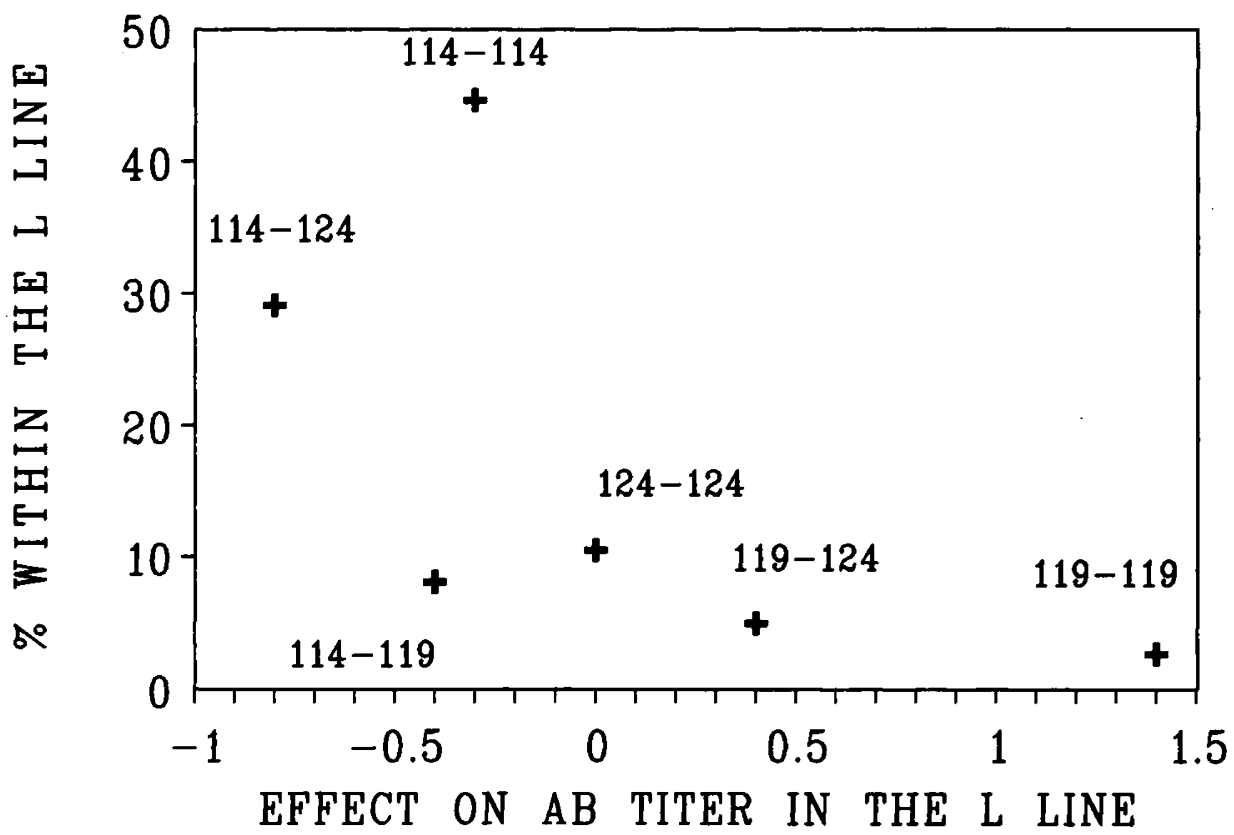

Fig 1. Frequencies of B-genotypes in the low $(\mathrm{L},+)$ line of the tenth generation, according to their effect on the $\mathrm{Ab}$ titer to SRBC, estimated from the low line.

species (Melnick et al, 1981; Østergard et al, 1989; Gautschi and Gaillard, 1990). Therefore, a possible effect of natural selection cannot be excluded. This, however, cannot explain the opposite changes in MHC type distributions in the $\mathrm{H}$ and $\mathrm{L}$ lines, as compared to the $\mathrm{C}$ line. The significant differences in effect of the MHC genotype on the selected trait are evidence for a direct or closely linked effect of $\mathrm{MHC}$ genes on the $\mathrm{Ab}$ response to SRBC.

The MHC type frequencies were not measured in the initial base population or in the first generations of selection. However, the control line was produced from the base population by random mating and displayed in the 10th generation all haplotype combinations, whereas the selected lines presented divergent distributions of MHC types. Given the relatively low level of inbreeding in the $\mathrm{C}$ line, it thus seems reasonable that the frequencies in the $\mathrm{C}$ line represent the distribution of $\mathrm{MHC}$ types in the base population, and that the MHC type frequencies have changed in the selected lines.

Changes in MHC gene frequency, or at least, differences in MHC type distributions between lines selected for immune responsiveness or disease resistance have been reported (Gavora et al, 1986; Heller et al, 1991). In a similar experiments to ours with chickens selected for high and low immune response to SRBC, differences in allelic frequency in 6 alloantigen systems including the B-system were found in an analysis of data from generations 10 to 13 (Dunnington et al, 1984; Martin et al, 1990). Interestingly, these authors reported that the most frequent B-haplotype in the $\mathrm{H}$ line was the 21 , which shares B-F antigens with the 121 B-haplotype, which 


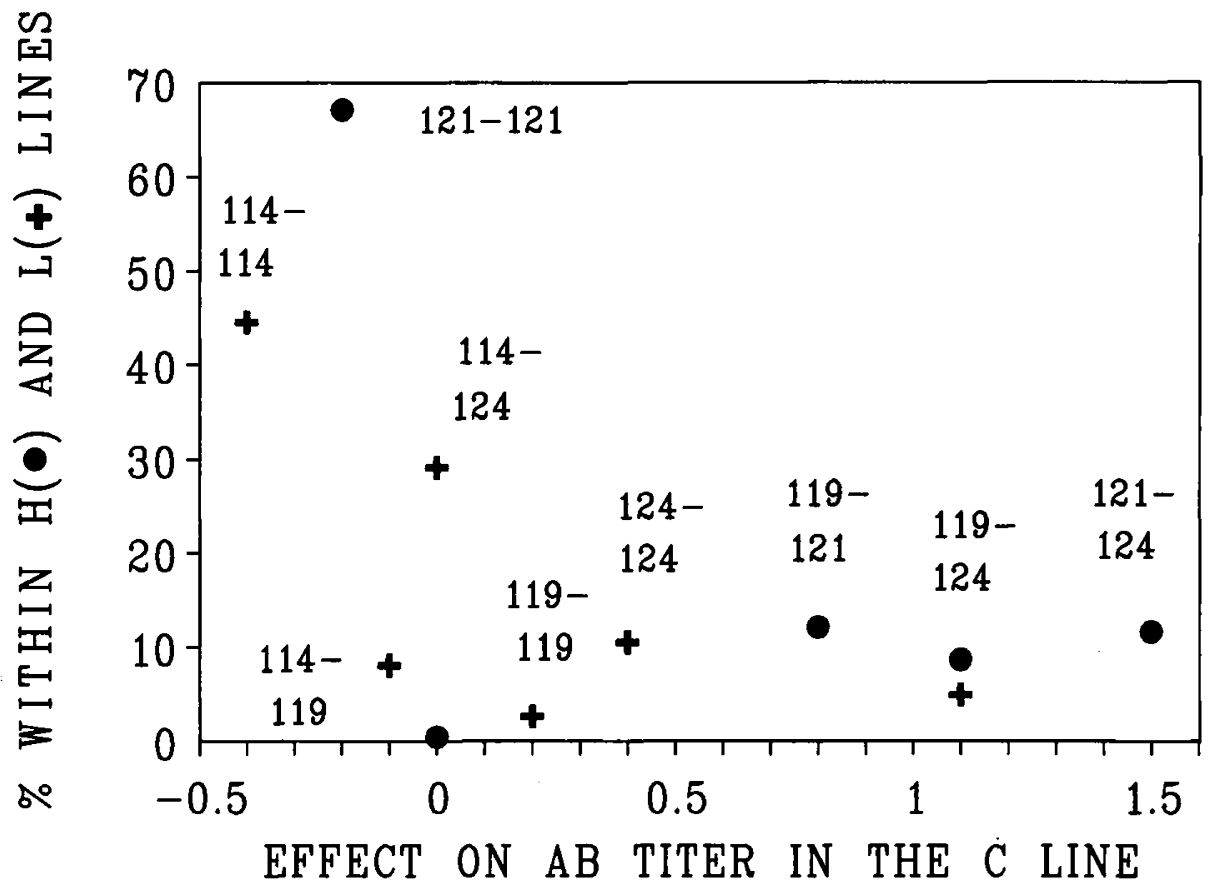

Fig 2. Frequencies of $B$-genotypes in the high $(\mathrm{H}, \bullet)$ and low $(\mathrm{L},+)$ lines of the tenth generation, according to their effect on the $\mathrm{Ab}$ titer to $\mathrm{SRBC}$, estimated from the control (C) line.

was also predominant in our $\mathrm{H}$ line (Pinard and Hepkema, 1992). Typing for MHC antigens in lines of mice divergently selected for $\mathrm{Ab}$ response to SRBC (Biozzi et $a l, 1979)$ also revealed 2 distinct haplotypes in the 2 lines (Colombani et al, 1979).

Estimation of MHC genotype effect and of heterozygote advantage produced different results between the lines. Immune responsiveness to various antigens like SRBC has been demonstrated to be influenced by non-MHC as well as by MHC genes (Palladino et al, 1977; Gyles et al, 1986; Kim et al, 1987; Lamont and Dietert, 1990). Significant interactions between MHC and the selected background genome were also reported in a similar selection experiment to ours (Dunnington et al, 1989). In addition, specific heterozygote advantage may result from genetic complementation between both MHC and non-MHC genes.

In segregating populations, the estimation of single gene effects can lead to biased results because of the likely confounding effects between the marker gene and the polygenes (Bentsen and Klemetsdal, 1991). Selection is an extra source of bias because the birds being selected are likely sharing advantageous alleles for both the marker gene and the polygenes. Kennedy et al (1992) showed that unbiased estimates of a single gene effects can be obtained by mixed model analysis from a selected population if all the genotypes are known. In our experiment, the genotypes were not determined in the early generations. And we chose to use the data complete for both the $\mathrm{Ab}$ titer and the genotypes from the last 2 generations, instead 
of using data from all generations with an unknown genotype. Indeed, Carnier and Arendonk (1992) demonstrated by simulation that including observations in previous generations of which genotype information was missing resulted in larger biases. In our estimation, bias due to selection could not be eliminated by the use of the complete relationship matrix only. This bias might have contributed to the differences in genotypic effects observed between the lines.

The present and previous results (Pinard et al, 1992) are in agreement with a polygenic control of antibody response to SRBC. Moreover, one of the loci involved might be part of, or linked to, the B-complex. However, the linkage and the nature of the interactions between $\mathrm{MHC}$ or MHC-linked genes and other immune response genes are not known. Besides, during 10 generations of multiple matings, recombinations between MHC-linked and other immune response genes might have occurred, causing altered linkage (Pevzner et al, 1978; Lamont; 1989).

In conclusion, results of the estimation of $\mathrm{MHC}$ effect from selected populations should be considered with caution, especially when the genotypes are not known in all the generations. In our experiment, estimation of MHC effect may be obtained from the control line, providing a larger number of birds. Alternatively, one could study a $\mathrm{F}_{2}$ population that will be produced from the high and low lines.

\section{REFERENCES}

Bacon LD (1987) Influence of the major histocompatibility complex on disease resistance and productivity. Poultry Sci 66, 802-811

Bentsen HB, Klemetsdal G (1991) The use of fixed effects models and mixed models to estimate single gene associated effects on polygenic traits. Genet Sel Evol 23, 407-419

Biozzi G, Mouton D, Heumann AM, Bouthillier Y, Stiffel C, Mevel JC (1979) Genetic analysis of antibody responsiveness to sheep erythrocytes in crosses between lines of mice selected for high or low antibody synthesis. Immunology 36, 427-438 Carnier P, Arendonk JAM (1992) Estimation of effects of single genes on quantitative traits in populations under selection. A simulation study. In: Proc 43rd Annu Meet EAAP. Madrid, 13-17 September 1992 1, 156

Colombani MJ, Pla M, Mouton D, Degos L (1979) H-2 typing of mice genetically selected for high or low antibody production. Immunogenetics 8, 237-243

Dunnington EA, Briles RW, Briles WE, Gross WB, Siegel PB (1984) Allelic frequencies in eight alloantigen systems of chicken selected for high and low antibody response to sheep red blood cells. Poultry Sci 63, 1470-1472

. Dunnington EA, Martin A, Briles RW, Briles WE, Gross WB, Siegel PB (1989) Antibody response to sheep erythrocytes for White Leghorn chickens differing in haplotypes of the major histocompatibility complex (B). Anim Genet 20, 213-216 Falconer DS (1989) Introduction to Quantitative Genetics. Longman Scientific and Technical, New York, 3rd edn

Gautschi C, Gaillard C (1990) Influence of major histocompatibility complex on reproduction and production traits in swine. Anim Genet 21, 161-170

Gavora JS (1990) New directions in poultry genetics. Disease genetics. In: Poultry Breeding and Genetics (Crawford RD, ed) Elsevier, 805-846 
Gavora JS, Simonsen M, Spencer JL, Fairfull RW, Gowe RS (1986) Changes in the frequencies of major histocompabitility haplotypes in chickens under selection for both high egg production and resistance to Marek's disease. J Anim Breed Genet $103,218-226$

Groeneveld E (1990) PEST User's Manual. Illinois Univ, Urbana, IL

Groeneveld E, Kovac M (1990) A generalised computing procedure for setting up and solving mixed linear models. J Dairy Sci 73, 513-531

Gyles NR, Fallah-Moghaddam H, Patterson LT, Skeeles JK, Whitfill CE, Johnson LW (1986) Genetic aspect of antibody response in chickens to different classes of antigens. Poultry Sci 65, 223-232

Heller ED, Uni Z, Bacon LD (1991) Serological evidence for major histocompatibility complex (B complex) antigens in broilers selected for humoral immune response. Poultry Sci 70, 726-732

Kennedy BW, Quinton M, van Arendonk JAM (1992) Estimation of effects of single genes on quantitative traits. J Anim Sci 70, 2000-2012

Kim CD, Lamont SJ, Rothschild MF (1987) Genetic association of body weight and immune response with the major histocompability complex in White Leghorn chicks. Poultry Sci 66, 1258-1263

Lamont SJ (1989) The chicken major histocompatibility complex in disease resistance and poultry breeding. J Dairy Sci 72, 1328-1333

Lamont SJ, Dietert RR (1990) New directions in poultry genetics. Immunogenetics. In: Poultry Breeding and Genetics (Crawford RD, ed) Elsevier, Amsterdam, 497541

Mallard BA, Kennedy BW, Wilkie BN (1991) The effect of swine leukocyte antigen haplotype on birth and weaning weights in miniature pigs and the role of statistical analysis in this estimation. J Anim Sci 69, 559-564

Martin A, Dunnington EA, Gross WB, Briles WE, Briles RW, Siegel PB (1990) Production traits and alloantigen systems in lines of chickens selected for high or low antibody responses to sheep erythrocytes. Poultry Sci 69, 871-878

Melnick M, Jaskoll T, Slavkin HC (1981) The association of H-2 haplotype with implantation, survival, and growth of murine embryos. Immunogenetics 14, 303-308 Nordskog AW, Pevzner IY, Lamont SJ (1987) Subregions and functions of the chicken major histocompatibility complex. Poultry Sci 66, 790-794

Østergard H, Kristensen B, Andersen S (1989) Investigations in farm animals of associations between the MHC system and disease resistance and fertility. Livest Prod Sci 22, 49-67

Palladino MA, Gilmour DG, Scafuri AR, Stone HA, Thorbecke GJ (1977) Immune response differences between two inbred chickens lines identical at the major histocompatibility complex. Immunogenetics 5, 253-259

Pevzner IY, Trowbridge CL, Nordskog AW (1978) Recombination between genes coding for immune response and the serologically determined antigens in the chicken B system. Immunogenetics 7, 25-33

Pinard MH, Hepkema BG (1992) Biochemical and serological identification of major histocompatibility antigens in outbred chickens. In: Selection for Immunoresponsiveness in Chickens: Effects of the Major Histocompatibility Complex and Resistance to Marek's Disease. Ph D Diss, Univ Wageningen, The Netherlands, 43-59 
Pinard MH, Hepkema BG, van der Meulen MA, Nieuwland MGB, van der Zijpp AJ (1991) Major histocompatibility complex haplotypes in chickens selected for high and low antibody production. Anim Genet 22 (supp 1), 117-118

Pinard MH, van Arendonk JAM, Nieuwland MGB, van der Zijpp AJ (1992) Divergent selection for immune responsiveness in chicken: estimation of realized heritability with an animal model. J Anim Sci 70: 2986-2993

Van der Zijpp AJ, Blankert JJ, Egberts E, Tilanus MGJ (1988) Advances in genetic disease resistance in poultry. In: Advances in Animal Breeding (Korver S, van der Steen HAM, van Arendonk JAM, Bakker H, Brascamp EW, Dommerholt J, eds) Pudoc, Wageningen, The Netherlands, 131-138

Warner CM, Meeker DL, Rothschild MF (1987) Genetic control of immune responsiveness: a review of its use as a tool for selection for disease resistance. J Anim Sci $64,394-406$ 